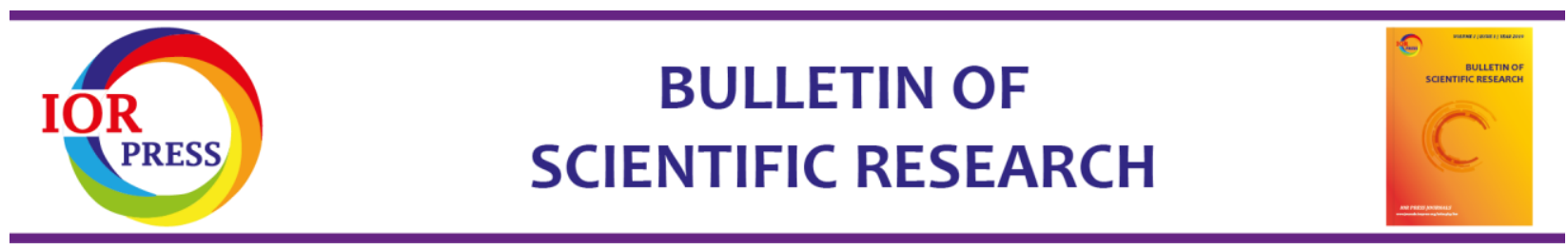

\title{
Isolation and characterization of drought stress tolerant plant growth promoting rhizobacter from chilli crop
}

\section{J. Devanathan a, ${ }^{*}$, T. Thiripurasundari a, K.A. Selvam a, A. Ram Kumar b, S. Selvaraj c,}

\section{Ramadass ${ }^{\mathrm{d}}$}

a PG and Research Department of Microbiology, Indo-American College, Cheyyar - 604407, Tamil Nadu, India.

b PG and Research Department of Biochemistry, Indo-American College, Cheyyar - 604407, Tamil Nadu, India.

c Department of Physics, Indo - American College, Cheyyar - 604407, Tamil Nadu, India.

${ }^{\mathrm{d}}$ Department of Chemistry, Indo - American College, Cheyyar - 604407, Tamil Nadu, India.

*Corresponding Author: jayadevanathan@gmail.com DOI: https://doi.org/10.34256/bsr2111

Received: $15-10-2020$

Accepted: 07-11-2020

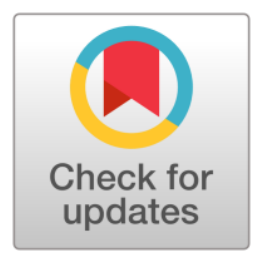

Abstract: Plant growth promoting rhizobacter (PGPR) are adapted to adverse conditions and protect plants from the deleterious effects of some environmental stresses. The aim of the present study, the drought tolerant plants growth promoting bacteria (PGRB) were isolate and characterized from chilli crop (CapsicumannumL). From the rhizosphere soil twelve bacteria were isolated and characterized based on their biochemical and sugar fermentation. The drought stress tolarent stains were screened by production of exo polysaccharides and the plant growth promoting activities like production of IAA and PO4 solubilization were screened. Therefore the present study report that PGRB showed good stress tolerance under drought condition in chilli crop.

Keywords: PGPR, Stress tolerant, Chilli crop, Exotic polysaccharide

\section{Introduction}

Nowadays, Plants are constantly exposed to a wide range of biotic and abiotic stresses which limit plant productivity. In world-wide Drought considered one of the most important multi dimensional stress inducing environmental factors that affect plant growth and yield, particularly in arid and semiarid regions. So, most of the work has been focused in understanding the mechanisms behind plant responses to various environmental stresses $[1,2]$.

Approximately, one-third of the world land area is prone to drought stress which poses severe threat to plant growth and food security [3]. In India where large populations depend on agriculture for their livelihoods, growth of agriculture assumes greater importance. The Indian agriculture mainly depend on two monsoon rains namely South West Monsoon and North East Monsoon. The recent failure in monsoon rain leaves $45 \%$ of the cropping area under drought (Indian Meteorological Department 2009). Thus drought negatively affects quantity and quality of growth in plants [4]. At the initial phase of plant growth and establishment, it negatively affects seed germination, stem elongation and expansion [5]. Reduced leaf growth and in turn the leaf areas caused a marked reduction in photosynthetic rate which subsequently decreased plant growth and yield [6]. Jaleel et al., 2009 reported that severe water stress 
produced deleterious effects on plant water relations, photosynthesis, ion uptake and nutrient metabolism as well as assimilates partitioning [7]. Therefore, world-wide extensive research is being carried out to develop strategies to cope with drought stress through development of drought tolerant varieties, shifting the crop calendars, resource management practices and most of these technologies are cost intensive. Recent studies indicate that microorganisms can also help plants to cope with drought stress. Plant growth promoting rhizobacter (PGPR) are adapted to adverse conditions and protect plants from the deleterious effects of some environmental stresses [8-10]. The rhizobacteria assemblages of many agricultural crops have been studied and the use of PGPR holds promise for plant growth promotion and alleviation of plant drought stress [11-13]. However, the drought-tolerant bacteria associated with crop species which are naturally adapted to drought, such as Chili have not been explored. Thus, the identification of beneficial microorganisms which mediate plant growth promoting activities and drought resistance in crop plants assumes greater importance. In the current study, the drought tolerant plant growth-promoting bacteria (PGPB) were isolate and characterized from chili crop (Capsicum annum L) with following objectives.

\section{Materials and methods}

\subsection{General Methods}

The following procedures were adopted for conducting various experiments during the research periods.

\subsubsection{Cleaning of glass wares}

The glass wares used in the present studies were soaked in cleaning solution $(100 \mathrm{~g}$ of Potassium dichromate was added to $1000 \mathrm{ml}$ of distilled water followed by addition of 500 $\mathrm{ml}$ of concentrated Sulphuric acid) for about 12 hours and washed in tap water. Finally, they were cleaned in distilled water, dried and used for the study.

\subsubsection{Sterilization}

The cleaned glass wares were sterilized at $180^{\circ} \mathrm{C}$ for 3 hours in a hot air oven. The media were sterilized in autoclave at $15 \mathrm{lbs}$ pressure $\left(121^{\circ} \mathrm{C}\right)$ for 20 minutes.

\subsubsection{Chemical and water}

All the chemicals used in the present studies were of Analytical Reagent (AR) grade and double distilled water was used throughout the studies.

\subsection{Collection of soil sample}

The samples of Chilli rhizosphere soil were collected from four different locations like Cheyyar, Madipakkam, Perungalathur, Kiliyathur.

\subsection{Estimation of microorganism from chilli rhizosphere soil by serial dilution technique}

After, 10 grams of chilli rhizosphere soil sample was mixed with $100 \mathrm{ml}$ of sterilized distilled water to get $10^{-1}$ dilution, transferred $1 \mathrm{ml}$ of $10^{-1}$ to $9 \mathrm{ml}$ sterilized water blank to get $10^{-2}$ dilution were continued till $10^{-6}$ to $10^{-7}$ dilution. Transferred $1 \mathrm{ml}$ aliquot from required dilutions to pertriplates, $10^{-6}$ and $10^{-7}$ dilutions were used of bacteria. The melted and cooled media was transferred to respective pre labeled plates like nutrient agar media for bacterial plates. After plating, plates were kept for incubation about 24 to 48 hours for bacteria maintained at temperature of $35^{\circ} \mathrm{C}$. From the total bacterial count plates, isolates which showed distinct colony characters were 
isolated in nutrient agar plates. The pure culture was obtained by streak plate method.

\subsection{Characterization of the bacterial isolates from rhizosphere soil}

\subsubsection{Morphological tests}

The following morphological tests viz., cell shape and Gram reaction was carried out to characterize the isolates.

\subsubsection{Cell shape}

The purified cultures, at a log phase were observed microscopically for the cell morphological characters [14].

\subsubsection{Gram staining}

A loop full of the above culture was taken and smeared on the glass slide and heat fixed. After staining the smear was observed under oil immersion objective.

\subsection{Biochemical characterization of test isolates}

Physiological and metabolic characteristics of the microorganisms were assessed through biochemical tests.

\subsubsection{Indole test}

A loop full of the isolated culture was inoculated into the tryptone broth. The Kovac's reagent was added after the incubation periods of 24-48 hours to broth and shacked gently. Development of red color ring in the top layer of the tube was considered as positive result.

\subsubsection{Methyl red reduction test}

MR broth was inoculated with a test organism and incubated at $37^{\circ} \mathrm{C}$ for 24-48 hours. The red color was formed when the
Methyl Red indicator was added in an evidence of positive result. Whereas there is no color change indicates a negative result [15].

\subsubsection{Voges Proskauer test (VP)}

VP broth was inoculated with the test organism and incubated at $37^{\circ} \mathrm{C}$ for 24-48 hours. The tube was shacked gently then allowed to remain undistributed for 10 to 15 minutes before the reaction is read. Formation of brownish red color indicated positive result. Whereas there is no color change indicates a negative result.

\subsubsection{Citrate utilization test}

Simmons citrate agar slant was streaked with isolated culture and incubated at $37^{\circ} \mathrm{C}$ for 24 to 48 hours. Color change from green to deep blue indicates positive result. The result was noted [15].

\subsubsection{Carbohydrate fermentation test}

The term sugar in microbiology denotes any fermentable substance. They may be monosaccharides, disaccharides, trisccharide, alcohols, glycosides and non-carbohydrate substances as inositol. The sugars were fermented by various types of bacteria and in that process acid and gas was produced which were indicated by the color indicated by the indicators for acid and gas collected into the inverted Durham's tube. The nutrient broth was prepared in $100 \mathrm{ml}$ quantity with different carbon sources such as Dextrose, Fructose, Lactose, Maltose, Mannitol, Sucrose and Xylose transferred to test tubes with durham's tube and sterilized. The loopful of the test culture was inoculated to the broth and incubated color change from red to yellow indicates the acid production. Gas production is seen with the help of Durham's tube. If the medium reminds unchanges then the culture is a nonfermentative. Acid with gas or without gas reveals that the culture is fermentative. 


\subsubsection{Triple sugar iron test}

The triple sugar iron agar medium was prepared, sterilized and dispensed into sterile test tubes. Slants were made and incubated with the test organism. The test tubes were incubated at $37^{\circ} \mathrm{C}$ for 24 hours. The result was observed and used for identification of the isolates.

\subsubsection{Nitrate reduction test}

Nitrate broth was prepared, sterilized and dispensed into sterile test tubes. The test organisms are inoculated into the nitrate broth. The test tubes were incubates at $37^{\circ} \mathrm{C}$ for 24 hours. The result was observed and used for identification of the isolates.

\subsubsection{Catalase test}

Catalase acts as a catalyst in the breakdown of hydrogen peroxide to oxygen and water. 24 hours old test organism was taken in a sterile wooden stick or a glass rod and was immersed in a hydrogen peroxide solution. Development of immediate bubbling indicates that the organism posses catalase enzyme [16]. The result was observed and used for identification of the isolates [17].

\subsubsection{Oxidase test}

Some bacteria possess the enzymatic oxidase that forms the part of the electron transport system. The enzymes oxidase the reagent $\mathrm{N}-\mathrm{N}$ tetra methyl paraphenyl diamine dihrdrochloride to coloured product indo phenols. When the growth of the organism was rubbed over the filter paper containing this reagent, purple color development. Oxidase disc was placed on the clean slide and 24 hours growth of culture was placed over the disc. The result were observed within 10 seconds .purple color indicate the positive result, no purple color change indicate negative result. The result was recorded and used for identification of the isolates.

\subsection{Screening for drought resistance activities of PGPR}

\subsubsection{Screening for Exo-polysaccharide}

Rhizobacter isolates were grown on YMG agar medium were inoculated in YMG broth and pre incubated at $25^{\circ} \mathrm{C}$ for 24 hours. $200 \mu \mathrm{l}$ of culture broth was inoculated into 50 $\mathrm{ml}$ of YMG broth and incubated at $25^{\circ} \mathrm{C}$ for 5 days at $120 \mathrm{rpm}$. Elimination of cells was followed by centrifugation $(10,000 \mathrm{rpm}$ for 20 min). The culture broth was mixed with 3 volumes of ethanol and after standing at $4^{\circ} \mathrm{C}$ for 24 hours, it was centrifuged at 10,000 rpm in $4^{\circ} \mathrm{C}$ for $20 \mathrm{~min}$. The weight of the precipitated EPS, were measured after drying at $80^{\circ} \mathrm{C}$ for 3 days.

\subsection{Screening for plant growth promoting activities of PGPR}

\subsubsection{Screening for IAA production}

The Indole-3-acetic acid

producing rhizobacter isolates were grown in LB broth supplemented with $5 \mathrm{mM}-1$ tryptophan for $48 \mathrm{~h}$ and their IAA producing ability was detected according to Bric et al., 1991 [18]. The culture were centrifuged at $10,000 \mathrm{rpm}$ for $15 \mathrm{~min}$ and $2 \mathrm{ml}$ supernatant was transferred into a tube to which $100 \mu \mathrm{l}$ of $10 \mathrm{mM}$ 0-phosphoric acid and $4 \mathrm{ml}$ of Salkowaski reagent $\left(1 \mathrm{ml}\right.$ of $0.5 \mathrm{M} \mathrm{FeCl}_{3}$ in $50 \mathrm{ml}$ $\left.35 \%(\mathrm{v} / \mathrm{v}) \mathrm{HClO}_{4}\right)$ were added. The mixture was incubated at room temperature for $25 \mathrm{~min}$. The tubes were observed for the development of pink color and their absorbance was measured at $530 \mathrm{~nm}$. The IAA concentration was determined against standard curve constructed from different concentrations of indole-3-acetic acid.

2.7.2. Screening for phosphate solubilization

The phosphate solubilization of the rhizobacter isolates were characterized by using Pikovskaya's medium [19]. The 
Pikovskaya agar plates were prepared and inoculate with $10 \mu \mathrm{l}$ of rhizobacter isolates grown in Pikovskaya broth to the exponential phase. After inoculation plates were incubating at $30^{\circ} \mathrm{C}$ for 3 days, formation of a clear zone around the spot was checked.

\section{Results and discussions}

\subsection{Collection of rhizosphere soil}

The sample of Chilli rhizosphere soils were collected from different location near by Cheyyar, Madipakkam, Perungalathur and Kiliyathur

\subsection{Estimation of microorganism from chilli} rhizosphere soil by serial dilution technique

The amount of bacteria present in rhizosphere soils were estimated by pour plate method and results were showed in Table 1 . Among the four samples Perungalathur rhizosphere soil showed highest population bacteria ( $5 \mathrm{X} 10^{7} \mathrm{CFU} / \mathrm{g}$ ), followed by Mamandur soil (4X10 $\mathrm{CFU} / \mathrm{g})$ and least amount of population was recorded by Cheyyar soil (1X107 CFU/g).

\subsection{Identification of the bacterial isolates by biochemical and sugar fermentation}

The isolated 12 bacterial isolates were characterized based on their biochemical and sugar fermentation.
Table 1. Estimation of bacteria from chilli rhizosphere soil

\begin{tabular}{|l|l|lr|}
\hline S.No & Location & $\begin{array}{l}\text { Avg.No } \\
\text { present } \\
\text { rhizosphere } \\
(\mathrm{CFU} / \mathrm{g})\end{array}$ & $\begin{array}{r}\text { Bacteria } \\
\text { in } \\
\text { soil }\end{array}$ \\
\hline 1 & Cheyyar & $1 \mathrm{X} 10^{7}$ & \\
\hline 2 & Mamandur & $4 \mathrm{X} 10^{7}$ & \\
\hline 3 & Madipakkam & $2 \times 10^{7}$ & \\
\hline 4 & Perungalathur & $5 \times 10^{7}$ & \\
\hline
\end{tabular}

The morphology of isolates were studied by Gram staining techniques, from the results five isolates were showed Gram negative Rods, four isolates Gram positive Cocci and three isolates gram positive rods viewed in Fig 1. The isolates were characterized based on their biochemical characters like, IMViC, TSI, catalase, oxidase and nitrate reduction followed by sugar (Dextrose, Fructose, Maltose, Sucrose, Mannitol and Xylose) fermentation test 12 isolates were identified like ISO-1 as Klebsiella sp, ISO-2 \& 5 as Staphylococcus sp, ISO-3\&7 as Bacillus sp, ISO-4 as Serratia sp, ISO6 as Streptococcus sp, ISO-8\&9 as Pseudomonas sp, ISO-10 as Azospirillum sp, ISO-11 as Azotobacter sp and ISO-12 Enterobacter sp The results were tabulated in Table 2 and also presented in the Fig 2.

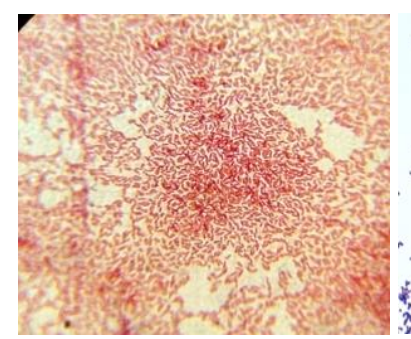

Klehsiella

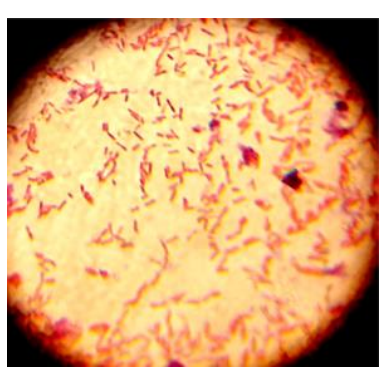

Serrat

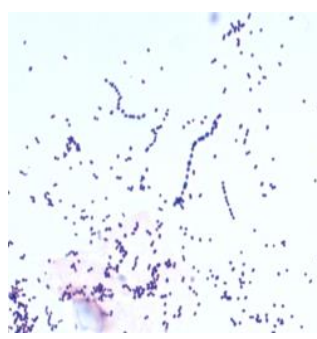

Staphyloco

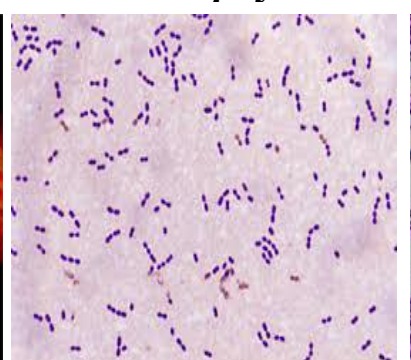

Staphvloco

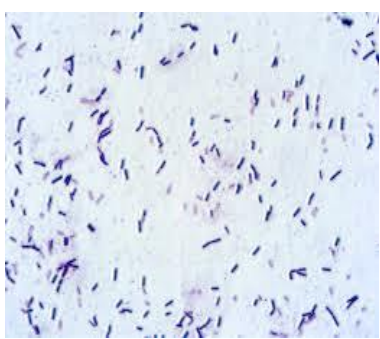

Bacillus

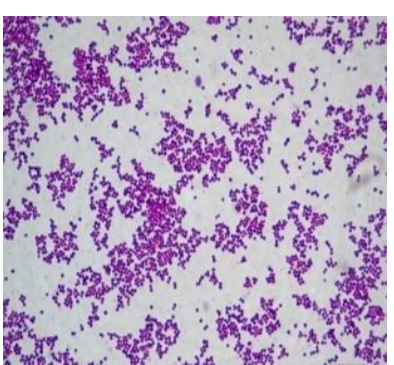

Strebtoco

Figure 1 Gram's staining of bacterial isolates. 
Table 2 Morphological and biochemical characterization of bacterial isolates

\begin{tabular}{|c|c|c|c|c|c|c|c|c|c|c|c|c|c|}
\hline $\begin{array}{l}\text { S. } \\
\text { No }\end{array}$ & Characters & ISO-1 & ISO-2 & ISO-3 & ISO-4 & ISO-5 & ISO-6 & ISO-7 & ISO-8 & ISO-9 & ISO-10 & ISO- 11 & ISO-12 \\
\hline \multirow[t]{2}{*}{1} & $\begin{array}{c}\text { Gram } \\
\text { staining }\end{array}$ & - & + & + & - & + & + & + & - & + & - & - & - \\
\hline & Shape & Rod & Cocci & Rod & Rod & Cocci & Cocci & Rod & Rod & Rod & Rod & Rod & Rod \\
\hline \multirow[t]{9}{*}{2} & $\begin{array}{c}\text { Biochemical } \\
\text { Test }\end{array}$ & & & & & & & & & & & & \\
\hline & Indole & - & - & - & - & - & - & - & - & - & - & + & - \\
\hline & Methyl red & - & - & - & - & - & - & - & - & - & - & + & - \\
\hline & $\begin{array}{c}\text { Vogus } \\
\text { proskauer }\end{array}$ & + & + & + & + & + & + & + & - & - & + & - & + \\
\hline & Citrate & + & + & + & + & + & + & + & + & + & + & + & + \\
\hline & TSI & + & + & + & - & + & + & - & + & + & + & + & - \\
\hline & Catalase & + & + & + & + & + & + & + & + & + & + & + & + \\
\hline & Oxidase & + & + & + & + & + & + & + & + & + & + & + & + \\
\hline & $\begin{array}{c}\text { Nitrate } \\
\text { Reduction }\end{array}$ & + & + & + & + & + & + & + & + & + & + & + & + \\
\hline \multirow[t]{8}{*}{3} & $\begin{array}{c}\text { Sugar } \\
\text { fermentatio } \\
\mathbf{n}\end{array}$ & & & & & & & & & & & & \\
\hline & Dextrose & + & + & + & + & + & + & + & + & + & + & + & + \\
\hline & Fructose & + & + & + & + & + & + & + & - & - & + & + & + \\
\hline & Lactose & + & - & variable & - & - & - & - & - & - & + & - & - \\
\hline & Maltose & + & + & + & + & + & + & + & - & - & + & - & - \\
\hline & Mannitol & + & + & + & + & + & - & + & + & + & + & - & - \\
\hline & Sucrose & + & + & + & + & + & - & + & - & - & + & + & + \\
\hline & Xylose & + & + & + & + & + & + & + & + & + & + & + & + \\
\hline \multicolumn{2}{|r|}{ Identified as } & $\begin{array}{l}\text { Klebsiella } \\
\text { sp }\end{array}$ & $\begin{array}{c}\text { Staphylo } \\
\text { coccus } \\
\text { sp } \\
\end{array}$ & $\begin{array}{l}\text { Bacillus } \\
\mathrm{sp}\end{array}$ & Serratiasp & $\begin{array}{l}\text { Staphylo } \\
\text { Coccus sp }\end{array}$ & $\begin{array}{l}\text { Streptoc } \\
\text { occus }\end{array}$ & $\begin{array}{l}\text { Bacillus } \\
\mathrm{sp}\end{array}$ & $\begin{array}{l}\text { Pseudomonas } \\
\text { sp }\end{array}$ & $\begin{array}{l}\text { Pseudomon- } \\
\text { as sp }\end{array}$ & Azospi-rillum & Azato bacter & $\begin{array}{l}\text { Entero- } \\
\text { bacter }\end{array}$ \\
\hline
\end{tabular}




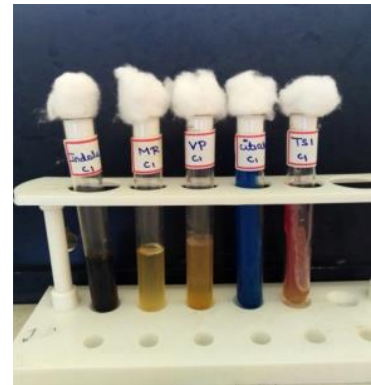

Klebsiella sp

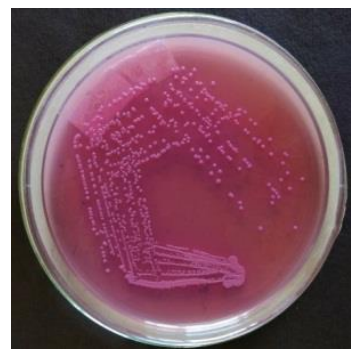

MacConkey Agar
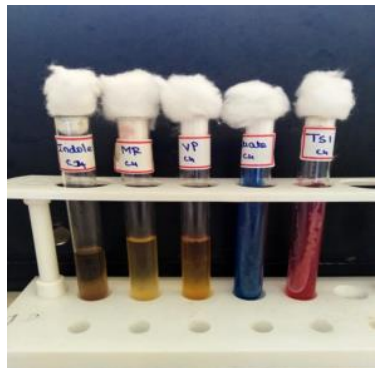

Serratia sp

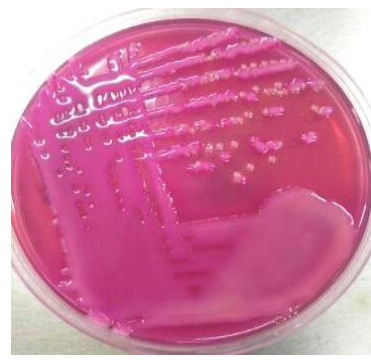

MacConkey agar

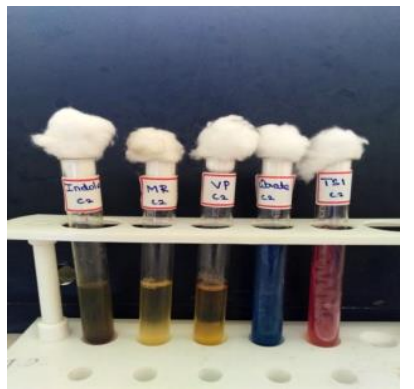

Staphylococcus aureus

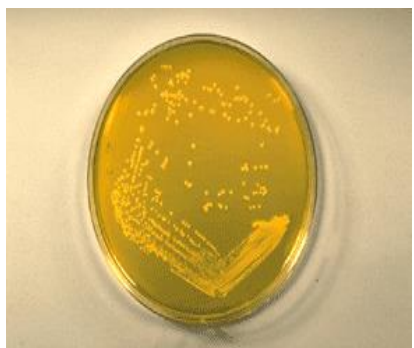

Mannitol Salt Agar

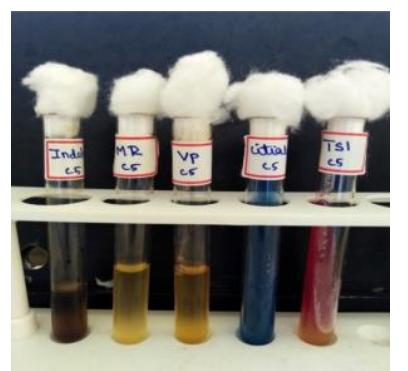

Staphylococcus sp

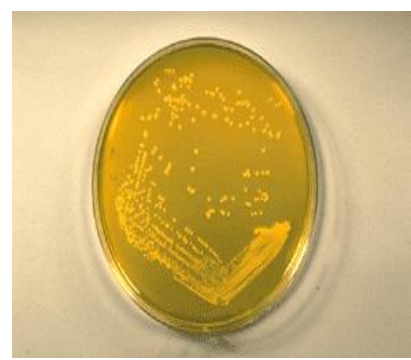

Mannitol Salt Agar

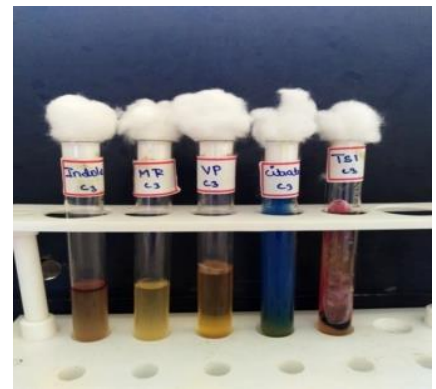

Bacillus sp

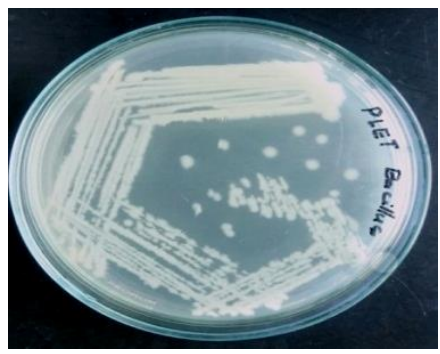

PLET Agar

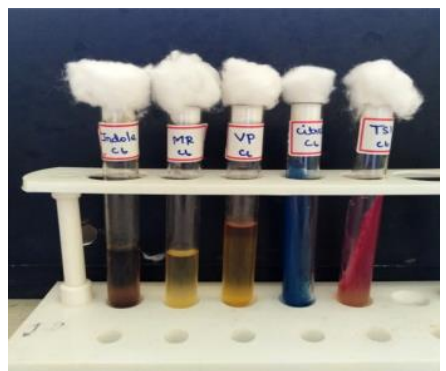

Streptococcus sp

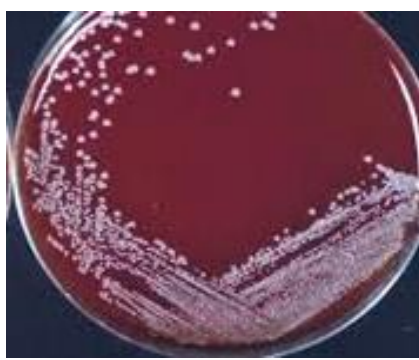

MacConkey Agar

Figure 2 Biochemical characterizations of bacterial isolate.s

3.4 Screening of drought tolerance from isolates by production of ExoPolysaccharide

The drought tolerant isolates were screened by production of exo-polysaccharide and the results were showed in Table 3. Among the 12 isolates, only 9 isolates exhibited exopolysaccharide production. The highest amount of exo-polysaccharide was recorded by Klebsiella sp $(0.41 \mathrm{mg} / 5 \mathrm{ml})$ followed by Pseudomonas sp $(0.33 \mathrm{mg} / 5 \mathrm{ml})$ and lowest amount of Serratia sp $(0.02 \mathrm{mg} / 5 \mathrm{ml})$. 
Table 3 Estimation of Exo - polysaccharide from the isolates

\begin{tabular}{|l|l|l|l|l|}
\hline \multirow{2}{*}{ S. No } & \multirow{2}{*}{ Name of Isolates } & \multicolumn{3}{|l|}{ Estimation of Exo-polysaccharide } \\
\cline { 3 - 5 } & & $\begin{array}{l}\text { Initial Weight } \\
(\mathbf{I})\end{array}$ & $\begin{array}{l}\text { Final weight } \\
\text { (F) }\end{array}$ & $\begin{array}{l}\text { Amount of } \\
\text { Exo-polysaccharide } \\
\text { (I-F) } \mathbf{~ m g / 5 m l ~}\end{array}$ \\
\hline 1 & Klebsiella sp & 1.86 & 1.45 & 0.41 \\
\hline 2 & Staphylococcus sp & - & - & - \\
\hline 3 & Bacillus $\mathrm{sp}$ & 1.55 & 1.51 & 0.04 \\
\hline 4 & Serratia $\mathrm{sp}$ & 1.54 & 1.52 & 0.02 \\
\hline 5 & Staphylococcus $\mathrm{sp}$ & - & - & - \\
\hline 6 & Streptococcus $\mathrm{sp}$ & - & - & - \\
\hline 7 & Bacillus $\mathrm{sp}$ & 1.55 & 1.51 & 0.04 \\
\hline 8 & Pseudomonas $\mathrm{sp}$ & 1.64 & 1.57 & 0.07 \\
\hline 9 & Pseudomonas $\mathrm{sp}$ & 1.87 & 1.54 & 0.33 \\
\hline 10 & Azospirillum $\mathrm{sp}$ & 1.62 & 1.48 & 0.14 \\
\hline 11 & Azotobacter $\mathrm{sp}$ & 1.49 & 1.46 & 0.03 \\
\hline 12 & Enterobacter $\mathrm{sp}$ & 1.54 & 1.49 & 0.05 \\
\hline
\end{tabular}

3.5. Screening of plant growth promoting activities from Isolates

The plant growth promoting activities like production of IAA and $\mathrm{PO}_{4}$ solubilization were screened from the Isolates by different methods.

\subsubsection{Estimation of IAA production from isolates}

The plant growth hormone IAA (1,3Indole Acetic Acid) producing isolates were screened and estimated their ability. The results were showed in Table.4. Among the 12 isolates, only 9 isolates can able to producing IAA. From the 9 isolates, Bacillus sp (1.36 $\mu \mathrm{g} \backslash \mathrm{ml}$ ) exhibited highest amount of production followed by Azotobacter sp $(1.29 \mu \mathrm{g} \backslash \mathrm{ml})$ and least amount of IAA production was recorded by Enterobacter sp $(0.63 \mu \mathrm{g} \backslash \mathrm{ml})$

\subsubsection{Estimation of Phosphate solubilization from isolates}

The plant growth promoting activities like $\mathrm{PO}_{4}$ solubilization was determined from the isolates and the results were tabulated in Table

5. From 12 isolates, 9 isolates only recorded zone of inhibition. Among the nine isolates Pseudomonas sp (18mm) showed highest zone of inhibition followed by Bacillus sp (17 mm) and least zone of inhibition was recorded by Enterobacter sp (01 $\mathrm{mm})$ the results also shown in the Fig 3.

Table 4 Estimation of IAA (1,3-Indole Acetic Acid) production from the isolates

\begin{tabular}{|l|l|l|}
\hline S.No & Name of Isolates & $\begin{array}{l}\text { IAA( } \boldsymbol{\mu g} \backslash \mathbf{m l}) \\
\text { Production } \\
\text { (OD } \mathbf{v a l u e ~} \text { at } \\
\mathbf{5 3 0} \mathbf{~ n m})\end{array}$ \\
\hline $\mathbf{1}$ & Klebsiella $\mathrm{sp}$ & 1.16 \\
\hline $\mathbf{2}$ & Staphylococcus $\mathrm{sp}$ & - \\
\hline $\mathbf{3}$ & Bacillus $\mathrm{sp}$ & 1.36 \\
\hline $\mathbf{4}$ & Serratia $\mathrm{sp}$ & 1.25 \\
\hline $\mathbf{5}$ & Staphylococcus $\mathrm{sp}$ & - \\
\hline $\mathbf{6}$ & Streptococcus $\mathrm{sp}$ & - \\
\hline $\mathbf{7}$ & Bacillus $\mathrm{sp}$ & 1.36 \\
\hline $\mathbf{8}$ & Pseudomonas $\mathrm{sp}$ & 1.23 \\
\hline $\mathbf{9}$ & Pseudomonas $\mathrm{sp}$ & 0.68 \\
\hline $\mathbf{1 0}$ & Asospirillum $\mathrm{sp}$ & 0.98 \\
\hline $\mathbf{1 1}$ & Azotobacter $\mathrm{sp}$ & 1.29 \\
\hline $\mathbf{1 2}$ & Enterobacter $\mathrm{sp}$ & 0.63 \\
\hline
\end{tabular}


Table 5 Estimation of $\mathrm{PO}_{4}$ solubilization

\begin{tabular}{|l|l|l|}
\hline S.NO & $\begin{array}{l}\text { Name of the } \\
\text { Isolates }\end{array}$ & $\begin{array}{l}\text { Zone of inhibition } \\
\text { (diameter in } \mathbf{~ m m} \text { ) }\end{array}$ \\
\hline $\mathbf{1}$ & Klebsiella $\mathrm{sp}$ & 10 \\
\hline $\mathbf{2}$ & Staphylococcus $\mathrm{sp}$ & - \\
\hline $\mathbf{3}$ & Bacillus $\mathrm{sp}$ & 16 \\
\hline $\mathbf{4}$ & Serratia $\mathrm{sp}$ & 02 \\
\hline $\mathbf{5}$ & Staphylococcus $\mathrm{sp}$ & - \\
\hline $\mathbf{6}$ & Streptococcus $\mathrm{sp}$ & - \\
\hline $\mathbf{7}$ & Bacillus $\mathrm{sp}$ & 17 \\
\hline $\mathbf{8}$ & Pseudomonas $\mathrm{sp}$ & 18 \\
\hline $\mathbf{9}$ & Pseudomonas $\mathrm{sp}$ & 17 \\
\hline $\mathbf{1 0}$ & Asospirillum $\mathrm{sp}$ & 08 \\
\hline $\mathbf{1 1}$ & Azotobacter $\mathrm{sp}$ & 06 \\
\hline $\mathbf{1 2}$ & Enterobacter $\mathrm{sp}$ & 01 \\
\hline
\end{tabular}

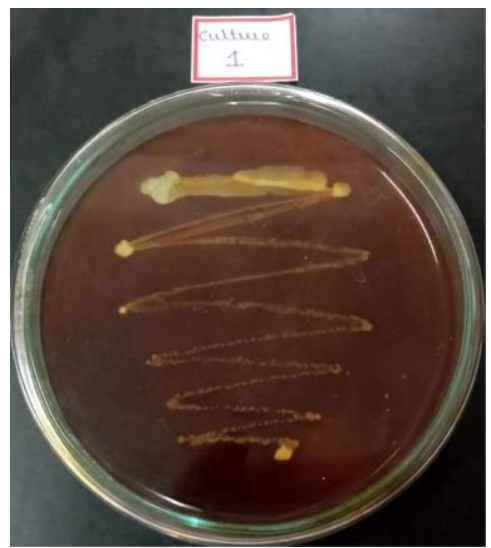

Klebsiella sp

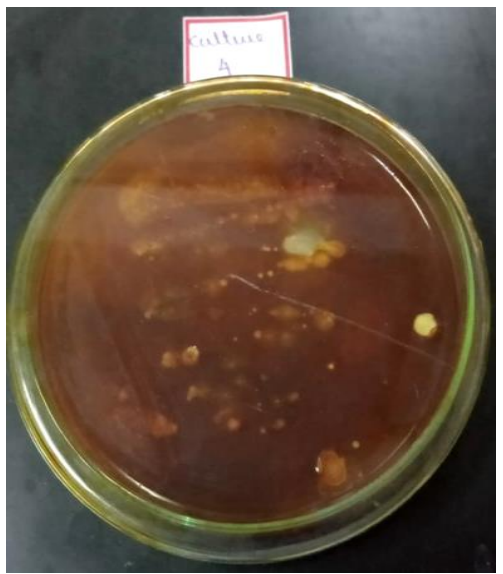

Serratia

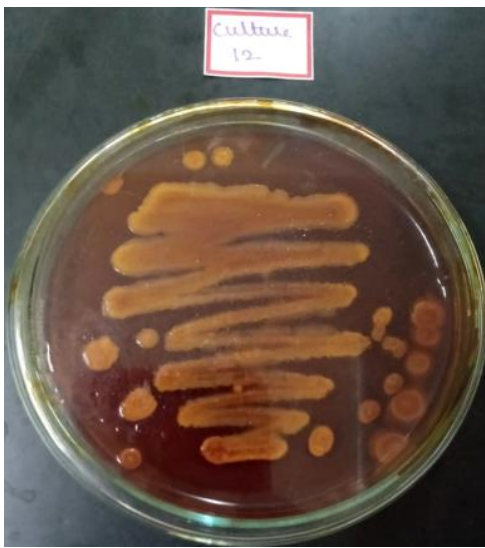

Enterobacter

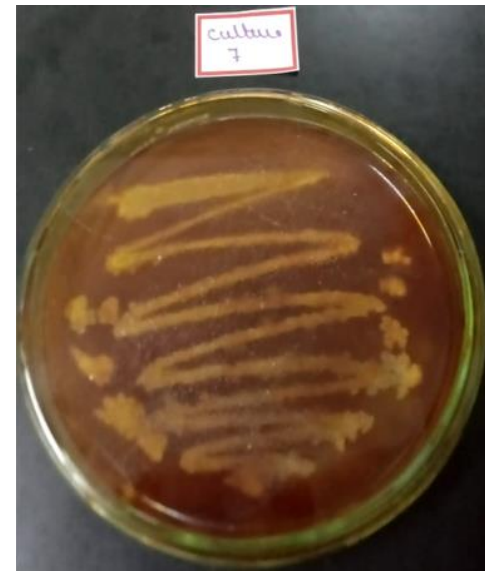

Bacillus

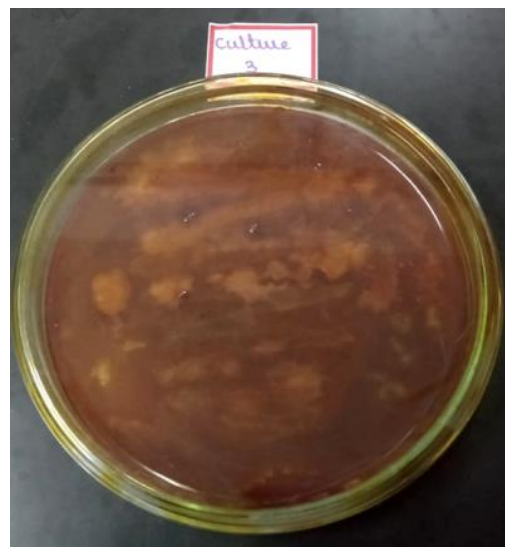

Bacillus

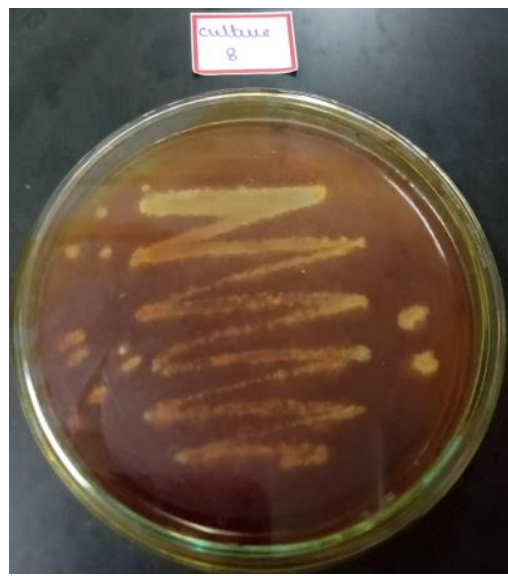

Pseudomonas

Figure 3 Estimation of phosphate solubility by zone of inhibition from the isolates 


\section{Conclusion}

The present investigation was undertaken to study the isolation and characterization of drought stress plant growth promoting rhizobacter form chili plant. There are 12 bacterial isolates were isolated and characterized based on their biochemical test and identified as Klebsiella sp, Staphylococcus $\mathrm{sp}$, Bacillus sp, Serratia sp, Staphylococcus sp, Streptococcus sp, Pseudomonas sp, Streptococcus sp, Asospirillum sp, Azotobacter sp and Enterobacter sp. The drought tolerant character was screened by production of Exopolysaccharide. The highest amount was recorded by Klebsiella sp $(0.41 \mathrm{mg} / 5 \mathrm{ml})$ followed by Pseudomonas sp (0.33 $\mathrm{mg} / 5 \mathrm{ml})$ and lowest amount of Serratia sp $(0.02$ $\mathrm{mg} / 5 \mathrm{ml}$ ). The PGPR activities were screened by production of IAA and PO4 solubilization. The highest amount of plant growth hormone like IAA was exhibited by Bacillus sp $(1.36 \mu \mathrm{g} \backslash \mathrm{ml})$ and least amount was recorded by Enterobacter sp $(0.63 \mu \mathrm{g} \backslash \mathrm{ml})$. The P04 solubilization was studied. The highest zone of inhibition was recorded by Pseudomonas sp (18mm) followed by Bacillus sp $(17 \mathrm{~mm})$ and least zone of inhibition was recorded by Enterobacter sp $(01$ $\mathrm{mm})$. Therefore the present study reported that PGPR showed good stress tolerate under drought conditions in chilli crops.

\section{References}

[1] M.F. Quartacci, C. Pinzino, C. Sgherri, F. Dalla Vecchia and F. Navari-Izzo, Growth in excess copper induces changes in the lipid composition and fluidity of PSII-enriched membranes in wheat, Physiologia Plantarum,108(1) (2000) 87-93, https://doi.org/10.1034/j.13993054.2000.108001087.x.

[2] C.L.M. Sgherri, M. Maffei and F. Navari-Izzo, Antioxidative enzymes in wheat subjected to increasing water deficit and rewatering, Journal of Plant Physiology, 157(3) (2000) 273-279. https://doi.org/10.1016/S0176-1617(00)80048-6.

[3] S. Yang, B. Vanderbeld, J. Wan and Y. Huang, Narrowing down the targets: towards successful genetic engineering of drought-tolerant crops, Molecular plant,3(3) (2010) 469-490. https://doi.org/10.1093/mp/ssq016.

[4] P. Rahdari and S.M. Hoseini, Drought stress: a review, International Journal of Agronomy and Plant Production, 3 (10) (2012) 443-446.

[5] I. Yardanov, V. Velikova and T. Tsonev, Plant responses to drought and stress tolerance, Bulgarian Journal of Plant Physiology Special Issue, (2003) 187-206. 
[6] V.C. Baligar, N.K. Fageria and Z.L. He, Nutrient use efficiency in plants, Communications in soil science and plant analysis, 32(7-8) 2001 921-950. https://doi.org/10.1081/CSS-100104098.

[7] C.A. Jaleel, P. Manivannan, A. Wahid, M. Farooq, H.J. Al-Juburi, R. Somasundaram, and R. Panneerselvam, Drought stress in plants: a review on morphological characteristics and pigments composition, International Journal of Agriculture and Biology, 11(1) (2009) 100105.

[8] B.R. Glick, C. Liu, S. Ghosh and E.B. Dumbroff, Early development of canola seedlings in the presence of the plant growth-promoting rhizobacterium Pseudomonas putida GR12-2. Soil Biology and Biochemistry, 29(8) (1997) 1233-1239. https://doi.org/10.1016/S00380717(97)00026-6.

[9] S. Timmusk and E.G.H. Wagner, The plant-growth-promoting rhizobacterium Paenibacillus polymyxa induces changes in Arabidopsis thaliana gene expression: a possible connection between biotic and abiotic stress responses, Molecular plant-microbe interactions, 12(11) (1999) 951-959. https://doi.org/10.1094/MPMI.1999.12.11.951.

[10] A. Marulanda, R. Porcel, J.M. Barea and R. Azcon, Drought tolerance and antioxidant activities in lavender plants colonized by native drought-tolerant or drought-sensitive Glomus species, Microbial ecology, 54(3) 2007 543, https://doi.org/10.1007/s00248-007-9237-y.

[11] S. Mayak, T. Tirosh and B.R. Glick, Plant growth-promoting bacteria that confer resistance to water stress in tomatoes and peppers, Plant Science, 166(2) (2004) 525-530. https://doi.org/10.1016/j.plantsci.2003.10.025.

[12] Z.A. Zahir, A. Munir, H.N. Asghar, B. Shaharoona and M. Arshad, Effectiveness of rhizobacteria containing ACC deaminase for growth promotion of peas (Pisum sativum) under drought conditions, Journal of Microbiol Biotechnology, 18(5) (2008) 958-963.

[13] V.Z.A.S. Sandhya, M. Grover, G. Reddy and B. Venkateswarlu, Alleviation of drought stress effects in sunflower seedlings by the exopolysaccharides producing Pseudomonas putida strain GAP-P45, Biology and fertility of soils, 46(1) (2009) 17-26. https://doi.org/10.1007/s00374-009-0401-z.

[14] J.H. Becking, Nitrogen-fixing bacteria of the genus Beijerinckia, Soil Science, 118(3), (1974) 196-212.

[15] H.W.Jr. Seeley and P.J. VanDemark, Microbes in action. A laboratory manual of microbiology, Microbes in action, A laboratory manual of microbiology (1962).

[16] J. Koneman, D. Allen, T. Janda, K. Schreckenberger and L. Winn, Microbiología diagnostic, (1988).

[17] J.G. Cappuccino and N. Sherman, Microbiology: a laboratory manual, The Benjamin/ cunnings publishing company Inc. (4th edition), Menlopark, California, (1996).

[18] J.M. Bric, R.M. Bostock and S.E. Silverstone, Rapid in situ assay for indoleacetic acid production by bacteria immobilized on a nitrocellulose membrane, Applied and environmental Microbiology, 57(2) (1991) 535-538.

[19] R.I. Pikovskaya, Mobilization of phosphorus in soil in connection with vital activity of some microbial species, Mikrobiologiya, 17 (1948), 362-370.

\section{Acknowledgement}

NIL

Funding

NIL. 


\title{
Authors Contribution
}

Conceptualization, methodology, manuscript preparation, review and editing (JD). Manuscript Review and Editing (TT, KAS, ARK, SS and LR). All the authors have read and approved the manuscript.

\section{Ethics Approval}

Approval was sought and granted by the Departmental Ethics Committee

\section{Conflict of interest}

The authors declare that they have no actual or potential conflict of interest, including financial, personal or other relationships with people or organizations that could have inappropriately influenced this work.

\author{
About The License \\ (C) The author(s) 2021. The text of this article is open access and licensed under a Creative Commons \\ Attribution 4.0 International License
}

